\title{
ANALISIS TANGGUNG JAWAB HUKUM NAKHODA TERHADAP KESELAMATAN PELAYARAN DI WILAYAH KESYAHBANDARAN UTAMA MAKASSAR
}

\author{
The Analisys of the Skippers' Legal Responsibility for Sailing Safety in Main Port Office Makassar
}

\author{
Badaruddin $^{1}$, Ruslan Renggong ${ }^{2}$, Abd. Haris Hamid ${ }^{3}$ \\ ${ }^{1}$ Magister Studi Ilmu Hukum Program Pascasarjana Universitas Bosowa \\ ${ }^{2}$ Program Studi Ilmu Hukum Program Pascasarjana Universitas Bosowa
}

Email: badaruddin@gmail.com

Diterima: 10 Januari 2021/Disetujui: 01 Juni 2021

\begin{abstract}
ABSTRAK
Penelitian ini bertujuan (a) untuk mengetahui pelaksanaan tanggung jawab hukum nakhoda terhadap keselamatan pelayaran. (b) untuk mengetahui faktor yang menyebabkan tidak terlaksananya tanggung jawab hukum nahkoda kapal. Metode penelitian yang digunakan adalah penelitian deskriftip yakni penelitian yang mengkaji permasalahan dengan menggunakan data primer dan data sekunder dengan cara melalui wawancara dan penyebaran koesioner terhadap responden ke lapangasn serta menggunakan buku-buku, artikel melalui penelusuran internet termasuk peraturan perundang-undangan yang berkaitan dengan permasalahan yang dibahas dalam penelitian ini. Hasil penelitian bahwa, Tanggung jawab nahkoda dalam keselamatan pelayaran merupakan tanggung jawab Nakhoda dan Nakhoda bisa lolos dari tanggung jawab itu hanya jika bisa dibuktikan sebaliknya, seorang Nakhoda kapal juga dapat di mintai tanggung jawab perdata jika terjadi tabrakan kapal di dermaga akibat kelalaian Nakhoda, Faktor yang menyebabkan tidak terlaksananya tanggung jawab Hukum Nakhoda Kapal disebabkan oleh faktor internal meliputi kurangnya kompetensi dan skill serta mental dan disiplin yang kurang dalam melaksanakan tugasnya dan kurangnya pemahaman tentang peraturan perundang-undangan pelayaran, dan kurangnya pengawasan dari pihak yang berwenang terhadap pelanggaran keselamatan pelayaran, faktor eksternal yaitu pengaruh cuaca buruk sehingga mengakibatkan kurangnya konsentrasi nakhoda dalam mengambil keputusan.
\end{abstract}

Kata Kunci : Tanggung Jawab, Nakhoda, Keselamatan Pelayaran

ABSTRACT

This study aims (a) to determine the implementation of the skippers' legal responsibility for sailing safety. (b) to determine factors that cause the non-compliance of the ship captain's legal responsibility. The research method used is descriptive research, that examines problems using primary data and secondary data by means of interviews and distributing questionnaires to respondents and using books, articles through internet searches, including laws and regulations relating to problems discussed in this study. The results of the study show that the responsibility of skippers in sailing safety is the responsibility of the captains and they can escape from that responsibility only if it can be proven, otherwise a captain can also be asked for civil liability if a ship collision at the dock happens due to the captain's negligence, factors causing the failure to carry out the legal responsibility of the captains due to internal factors including lack of competence and skill as well as inadequate mental and discipline in carrying out their duties and lack of understanding of sailing laws and regulations, and lack of supervision from the authorities regarding violations of sailing safety, external factors namely the influence of bad weather resulting in a lack of concentration of skippers in making decisions.

Keywords: Responsibility, Skippers and Sailing Safety

\section{PENDAHULUAN}

Negara Kesatuan Republik Indonesia sebagai Negara kepulauan yang memiliki luas daratan dan lautan yang terdiri dari wilayah laut teritorial dengan luas 290 ribu km yang merupakan $2 / 3$ luas wilayah nusantara sehingga total perairan 6,4 juta $\mathrm{km} 2$, sedangkan luas zona ekonomi eksklusif Indonesia adalah 3 juta $\mathrm{km} 2$, hal inilah yang menyebabkan pengangkutan melalui laut menjadi pilihan utama guna menjadi sarana penghubung antar pulau dan daerah di Indonesia, pengangkutan menjadi pilihan utama karena memiliki kelebihan dibandingkan dengan moda transportasi yang lain, diantaranya biaya pengangkutan yang lebih murah dibandingkan dengan alat angkut lainnya dan sanggup mengangkut barang-barang dalam jumlah banyak sampai ratusan atau ribuan ton sekaligus .

Melalui pengangkutan laut, baik orang maupun barang dapat diangkut dari satu tempat ketempat tujuan tertentu melalui pelabuhan-pelabuhan yang ada di seluruh Indonesia yang berjumlah 1887 pelabuhan. Menyadari bahwa 
pentingnya sarana transportasi tersebut, angkutan laut sebagai salah satu moda transportasi, di perairan harus di tata dalam satu kesatuan sistem transportasi nasional yang terpadu dan mampu mewujudkan penyediaan jasa transportasi yang seimbang sesuai tingkat kebutuhan dan tersedianya pelayanan angkutan yang aman, kantor kesyahbandaran dan otoritas pelabuhan mempunyai tugas melaksanakan pengawasan, dan penegakan hukum di bidang keselamatan dan keamanan pelayaran, koordinasi kegiatan pemerintahan di pelabuhan serta pengaturan, pengendalian dan pengawasan kegiatan kepelabuhanan pada pelabuhan yang diusahakan secara komersial.

Dalam undang-undang RI Nomor 17 Tahun 2008 (UUP) tentang pelayaran selanjutnya diatur dalam Pasal 116 ayat (1) disebutkan keselamatan dan keamanan pelayaran adalah suatu keadaan terpenuhinya persyaratan keselamatan dan keamanan yang menyangkut angkutan di perairan, kepelabuhanan dan lingkungan maritim. Selanjutnya keselamatan pelayaran secara internasional tercantum dalam Safety of life at Sea $($ SOLAS $) 1974$ Pasal IX yaitu International Safety Management (ISM) Code yang diperbaiki dengan amandemen 1978 berlaku bagi semua kapal yang melakukan pelayaran antara pelabuhan-pelabuhan di dunia. Salah satu hal yang perlu diperhatikan dalam keselamatan pelayaran yaitu pemanduan kapal. Pemanduan kapal dimulai saat kapal akan memasuki atau keluar dari kolam pelabuhan.

Moda transportasi air di Indonesia kembali menjadi perhatian dari berbagai pihak, setelah beberapa kecelakaan pelayaran terjadi. Berbagai penyebab kecelakaan pelayaran yang ditemukan mulai dari faktor pendukung keselamatan kapal hingga faktor cuaca buruk, namun sebenarnya apa yang salah dari berbagai kecelakaan pelayaran ini, masyarakat pada awalnya dihebohkan dengan tenggelamnya KM Sinar Bangun di perairan Danau Toba, Sumatera Utara pada Senin 18 Juni 2018 lalu. 18 penumpang selamat dan 3 penumpang meninggal dunia berhasil dievakuasi serta 180 penumpang lainnya hilang. Sesaat setelah kejadian, laporan korban hilang akibat tenggelamnya KM Sinar Bangun sempat simpang siur. Hal ini karena kapal tersebut berlayar dengan tidak memiliki data manifest penumpang.

Berdasarkan data dari kantor badan sar nasional di pelabuhan Tigaras, keluarga yang hilang sebanyak 186. Penumpang KM Sinar Bangun yang hilang akibat tenggelam berjumlah 94 orang teridentifikasi, sedangkan 92 orang belum diketahui identitasnya, selain itu KM Sinar Bangun juga berlayar dengan membawa penumpang melebihi kapasitasnya yang seharusnya berjumlah 43 orang. Kendali nakhoda kapal di luar aturan yang sebenarnya. Berkaitan dengan kapasitas kapal ini adalah 43 orang berdasarkan aturan kementerian perhubungan pencarian 180 orang korban hilang KM Sinar Bangun pun resmi ditutup pada hari Selasa 3 Juni 2018. Pada hari yang sama, kecelakaan pelayaran kembali terjadi di perairan Selayar, Sulawesi Selatan. Kapal jenis roro KM Lestari Maju, kapal tersebut kandas setelah menghadapi cuaca buruk saat berlayar. Kapal tersebut berlayar menuju penyeberangan Pamatata, kapal tersebut dinakhodai oleh Agus Susanto, dalam fakta laporan terjadi akibat ombak tinggi hingga air masuk ke kapal. Air masuk ke dalam kapal hingga akhirnya nakhoda mengandaskan kapal sekitar 300 meter dari Pantai Pa'badilang.

Keberadaan nakhoda dengan pandu laut di atas sebuah kapal niaga, sangat berperan menjaga keselamatan berlayar menuju pelabuhan tujuan. Pandu bandar dan nakhoda menjalankan tugas pada lingkungan kerjanya, wilayah pelabuhan memiliki tingkat kepadatan lalu lintas kapal tertinggi di Indonesia yang perlu dijaga. Kondisi keselamatan pelayaran yang diharapkan adalah mewujudkan Nakhoda kapal zero accident. Nakhoda mempunyai kekuasaan di kapal atas semua penumpang, mereka wajib menaati perintah yang diberikan oleh nakhoda untuk kepentingan keamanan atau untuk mempertahankan ketertiban dan disiplin, walaupun nakhoda berkedudukan sebagai buruh utama pengusaha kapal, dia memegang pimpinan kapal yang pada setiap peristiwa tertentu, nakhoda wajib bertindak sesuai dengan kecakapan, kecermatan dan kebijaksanaan yang cukup untuk melaksanakan tugasnya.

Nakhoda wajib menaati dengan seksama peraturan yang lazim dan ketentuan yang ada untuk menjamin kesanggupan berlayar dan keamanaan kapal, keamanan para penumpang dan pengangkutan muatannya, nakhoda tidak akan melakukan perjalanan kecuali bila kapalnya memenuhi persyaratan, dan dilengkapi sepantasnya serta diberi anak buah kapal secukupnya. Persyaratan keselamatan kapal pelayar dan muatan tercantum dalam Ordonansi Kapal 1935 dan sanggup melaksanakan perjalanan dimaksud. Nahkoda kapal di sini sebagai laik laut, unsur-unsur laik laut adalah stabilitas harus memadai, tindakan-tindakan pengamanan terhadap muatan, tata pemompaan harus berfungsi dan palka -palka harus ditutup kedap air.

Persyaratan pengawakan ditetapkan ordonansi Kapal 1935 dimana faktor berikut banyak menentukan ukuran kapal, perlengkapan, kekuatan mesin, sistem pengendalian mesin dan lain-lain kesemuanya diatur dalam Ordonansi Kapal 1935 dan Safety of life at sea (SOLAS)1974. Kewajiban umum yang harus ditaati seorang nakhoda adalah wajib mentaati peraturan-peraturan sebagai jaminan kelaikan dan keselamatan kapal para pelayarnya maupun muatannya. Kewajiban hukum ini dibebankan kepada nakhoda secara pribadi, perintah-perintah dari pengusaha kapal tidak dapat membebaskannya, nakhoda tidak terikat dengan perintahperintah tersebut jika hal itu bertentangan dengan kewajibankewajibannya menurut perundang-undangan.

Menurut Titik Triwulan bahwa pertanggungjawaban harus mempunyai dasar, yaitu hal yang menyebabkan timbulnya hak hukum bagi seseorang untuk menuntut orang lain untuk memberi pertanggung jawabannya. dalam hukum perdata dasar pertanggungjawaban dibagi menjadi dua macam, yaitu kesalahan dan risiko. Dengan demikian dikenal dengan pertanggungjawaban atas dasar kesalahan ( lilability without based on fault) dan pertanggungjawaban tanpa kesalahan yang dikenal (lilability without fault), sedangkan tanggung jawab risiko atau tanggung jawab mutlak dikenal dengan ( strick liabiliy). Prinsip dasar pertanggung jawaban atas dasar kesalahan mengandung arti bahwa seseorang harus bertanggung jawab karena ia melakukan kesalahan karena merugikan orang lain. sebaliknya prinsip tanggung jawab risiko adalah, bahwa konsumen penggugat tidak diwajibkan lagi melainkan produsen tergugat langsung bertanggung jawab sebagai risiko usahanya.

Menurut Abdul Kadir Muhammad tanggung jawab dalam perbuatan melanggar hukum (tort liability) dibagi menjadi beberapa teori, Yaitu: Pertama; tanggung jawab akibat perbuatan melanggar hukum yang dilakukan dengan sengaja (intertional tort liability), tergugat harus sudah melakukan perbuatan sedemikian rupa sehingga merugikan penggugat atau mengetahui bahwa apa yang dilakukan tergugat akan mengakibatkan kerugian. Kedua; tanggung jawab akibat perbuatan melanggar hukum yang dilakukan 
karena kelalaian (negligence tort lilability), didasarkan pada konsep kesalahan (concept of fault) yang berkaitan dengan moral dan hukum yang sudah bercampur baur (interminglend). Ketiga; adalah tanggung jawab mutlak akibat perbuatan melanggar hukum tanpa mempersoalkan kesalahan (stirck liability), didasarkan pada perbuatannya baik secara sengaja maupun tidak sengaja, artinya meskipun bukan kesalahannya tetap bertanggung jawab atas kerugian yang timbulkan artinya meskipun bukan bertanggung jawab atas kerugian yang timbulkan.

\section{METODE}

Data yang telah diperoleh dari hasil penelitian ini disusun dan dianalisis secara kualitatip, kemudian selanjutnya data tersebut diuraikan secara deskriptif guna memperoleh gambaran yang dapat di pahami secara jelas dan terarah untuk menjawab permasalahan yang penulis teliti.

Dalam melaksanakan penelitian ini peneliti telah menentukan lokasi penelitian yakni di kantor kesyahbandaran Makassar, pemilihan lokasi tersebut telah di pertimbangkan secara objektif untuk mendapatkan data yang akurat dan lengkap sehingga diharapkan menghasilkan sebuah penelitian ilmiah yang berkualitas, Adapun cara untuk mengumpulkan data yakni dengan teknik:

1. Teknik wawancara ( interview ) yaitu melakukan tanya jawab secara langsung dan mendalam dengan responden /narasumber yang telah ditentukan

2. Teknik Kepustakaan yaitu suatu teknik penelaan normatif dari beberapa data-data dan dokumen yang telah ada, peraturan perundang-undangan terkait, serta penelaan beberapa literatur yang relevan dengan penelitian ini

\section{HASIL DAN PEMBAHASAN}

3.1. Pelaksanaan Tanggung Jawab Hukum Nahkoda Kapal Atas Keselamatan Dalam Pelayaran Di Kesyahbandaran Utama Makassar

Peristiwa terjadinya kecelakaan kapal di laut dapat mengakibatkan kerugian baik secara materil maupun hilangnya nyawa orang. Atas peristiwa tersebut haruslah ada orang yang bertanggung jawab, terkecuali karena sesuatu yang bersifat faktor alam yang tidak dapat di cegah oleh manusia, misalnya terjadinya badai besar saat pelayaran. Peristiwa kecelakaan pelayaran secara umum disebabkan oleh faktor kesalahan manusia diantaranya Pemilik/Pengusaha Kapal; Syahbandar, nakhoda maupun pihak-pihak lain yang dapat mengakibatkan kecelakaan kapal.

1) Melengkapi alat keselamatan di atas kapal

Keselamatan kapal adalah keadaan kapal yang memenuhi persyaratan material, konstruksi, bangunan, permesinan dan pelistrikan, stabilitas tata susunan serta perlengkapan termasuk perlengkapan alat penolong dan radio elektronik kapal yang dibuktikan dengan sertifikat setelah dilakukan pemeriksaan dan pengujian terlebih dahulu, adapun contoh -contoh peralatan keselamatan yang ada di kapal adalah sekoci penyelamat (life boat), pelampung penolong bentuk cincin ( ring life buoys) jaket penolong ( life jackets), rakit penolong tiup ( inflatable liferaft), pelempar tali penolong ( line throwing apparatus ), media pelindung panas ( thermal proctive aid), dan isyarat asap ( phyrotechnis ) alat keselamatan sangatlah penting bagi crew kapal dan penumpang yang menggunakan jasa angkutan laut sebagai moda pengangkutan barang dan orang, diharuskan bagi crew kapal untuk dapat mengoprasikan dan merawat alat keselamatan yang ada di atas sehingga jika terjadi kecelakaan di laut dapat menolong diri sendiri dan orang lain dengan cepat dan tepat.

2) Mengawaki kapal secara layak sesuai prosedur pelayaran Nakhoda memikul tanggung jawab penting dalam sebuah kapal, secara umum tugas seorang nahkoda kapal adalah bertanggung jawab ketika membawa sebuah kapal dalam pelayaran baik itu dari pelabuhan satu menuju ke pelabuhan lainnya dengan selamat. Tanggung jawab itu meliputi keselamatan seluruh penumpang atau barang yang ada dalam kapal, Nakhoda kapal bertanggung jawab atas keselamatan para pelayar yang ada di atas kapalnya dan mematuhi perintah pengusaha kapal selama tidak menyimpang dari peraturan perundang-undangan yang berlaku

3) Memastikan kapal laik laut

Kelaiklautan kapal adalah keadaan kapal yang memenuhi persyaratan keselamatan kapal, pencegahan pencemaran perairan dari kapal, pengawakan, garis muat, pemuatan, kesejahteraan awak kapal dan kesehatan penumpang, status hukum kapal, menajemen keselamatan dan pencegahan pencemaran dari kapal, dan manajemen keamanan kapal untuk berlayar di perairan tertentu

4) Bertanggung jawab atas keselamatan pelayaran

Selain harus memeriksa keselamatan dan keamanan sebelum berlayar, seorang nakhoda juga harus melakukan upaya dalam mencegah kapal mengalami bahaya.

5) Bertanggung jawab atas keselamatan crew kapal Nakhoda bertanggung jawab terhadap awak kapal/ crew kapal, selama pelayaran, Nakhoda mewakili pengusaha/owner kapal membuat perjanjian kerja laut dengan anak buah kapal yang bekerja padanya, nakhoda menentukan peraturan-peraturan mengenai hubungan kerja antara perwira yang satu dengan yang lainnya atau antara awak kapal lainnya

6) Mematuhi perintah pengusaha kapal selama tidak menyimpang peraturan perundang-undangan yang berlaku.

Menurut Triono Kepala Bidang Keselamatan Berlayar kesyahbandaran utama Makassar tentang Pelaksanaan Tanggung Jawab Hukum Nakhoda Kapal Atas Keselamatan Dalam Pelayaran Di Kesyahbandaran Utama Makassar

1) Nakhoda adalah pimpinan tertinggi di atas kapal yang mempunyai tanggung jawab terhadap keselamatan kapal , awak kapal dan barang yang ikut di atas kapal, nakhoda bisa mengambil suatu tindakan apa saja yang bisa menyelamatkan kapal dari sebuah kecelakaan, oleh sebab itu nakhoda dituntut harus memiliki kompetensi dan keahlian yang diandalkan sehingga dapat dipertanggung jawabkan di hadapan hukum yang berlaku

2) Nakhoda akan lepas dari tanggung jawab hukum apabila terjadi suatu tindakan yang dilakuakan demi menyelamatkan kapal dan awaknya dari suatu musibah kecelakaan,dan bila terjadi kecelakaan akibat cuaca 
buruk yang dapat dibuktikan dihadapan pengadilan mahkama pelayaran

Menurut Iskandar, kepala cruwing Perusahaan Pelayaran PT Logindo Samudra Makmur, tentang Pelaksanaan Tanggung Jawab Hukum Nahkoda Kapal Atas Keselamatan Dalam Pelayaran ;

1) Nakhoda adalah wakil perusahaan di atas kapal yang telah diberikan tanggung jawab dan wewenang penuh secara hukum untuk memastikan keselamatan kapal, crew, muatan serta semua fasilitas yang ada di sekitar area operasi / pelayarannya mulai bertolak dari suatu tempat sampai tiba di pelabuhan tujuan

2) Nakhoda harus memastikan bahwa kondisi kapal laik laut dan hal ini harus dibuktikan dengan sertifikat keselamatan ( lambung, machinery, sertifikat perlengkapan alat keselamatan ) yang telah di lakukan pemeriksaan atau pengujian oleh badan sertifikasi

3) Keselamatan pelayaran juga sangat tergantung pada persiapan nakhoda sebelum melakukan pelayaran dimana harus memastikan rute pelayaran yang akan di lewati, memastikan semua sarana prasarana alat keselamatan dan alat komunikasi berfungsi dengan baik, kondisi mesin dan semua mesin bantu berfungsi normal, perhitungan bahan bakar dan logistik cukup sampai tujuan, dan perhitungan kondisi cuaca serta marine hazard atau navigasi selama pelayaran.

Selama pelayaran, nakhoda harus memastikan sistim jaga terlaksana dengan baik dan selalu memastikan kapal berlayar di alur yang sudah ditentukan. Terkait dengan tanggung jawab nakhoda sebagaimana tersebut di atas, maka berikut ini akan di kemukakan perihal pelaksanaan tanggung jawab nakhoda kapal sebagaimana dalam tabel berikut ini:

Tabel 1

Jawaban Informan Tentang Berapa Kali Menggunakan Moda Transportasi Laut

\begin{tabular}{|c|c|c|c|}
\hline No & Kategori Jawaban & $\begin{array}{c}\text { Frekuensi } \\
\text { (orang) }\end{array}$ & $\begin{array}{c}\text { Presentase } \\
(\%)\end{array}$ \\
\hline 1 & $>2$ & 20 & 40 \\
\hline \multirow[t]{2}{*}{2} & $>4$ & 30 & 60 \\
\hline & Jumlah & 50 & 100 \\
\hline
\end{tabular}

Sumber data : Kuesioner diolah Desember 2020

Berdasarkan tabel di atas, maka dari jumlah 50 responden yang telah dibagikan kousener terkait dengan pertanyaan berapa kali menggunakan moda transportasi laut, maka terdapat 20 orang (40\%) menjawab lebih dari 2 kali dan 30 orang $(60 \%)$ menjawab lebih dari 4 kali, hal ini menunjukkan bahwa responden masih lebih banyak menggunakan moda transportasi laut

Tabel 2

Jawaban Informan Tentang Bagaimana Pelayanan Selama Dalam Pelayaran

\begin{tabular}{llcc}
\hline No & Kategori Jawaban & $\begin{array}{c}\text { Frekuensi } \\
\text { (Orang) }\end{array}$ & $\begin{array}{c}\text { Presentase } \\
(\%)\end{array}$ \\
\hline 1 & Memadai & 20 & 40 \\
2 & Tidak Memadai & 30 & 60 \\
\hline & Jumlah & 50 & 100 \\
\hline
\end{tabular}

Sumber Data: Kuesioner diolah Desember 2020

Berdasarkan tabel di atas, maka dari sejumlah 50 responden yang telah diberikan koesioner, terkait pertanyaan tentang bagaimana pelayanan selama pelayaran, ada 20 orang ( $40 \%$ ) menjawab pelayanan memadai dan 30 orang ( $60 \%$ ) menjawab pelayanan tidak memadai, hal ini menunjukkan bahwa kualitas pelayanan masih menjadi hal yang masih perlu ditingkatkatkan.

Tabel 3

Jawaban Informan Tentang Fasilatas Apakah Lengkap AtauTidak Lengkap

\begin{tabular}{clcc}
\hline No & Kategori Jawaban & $\begin{array}{c}\text { Frekuensi } \\
\text { (orang) }\end{array}$ & $\begin{array}{c}\text { Presentase } \\
(\%)\end{array}$ \\
\hline 1 & Lengkap & 35 & 70 \\
2 & Tidak Lengkap & 15 & 30 \\
\hline & Jumlah & 50 & 100 \\
\hline
\end{tabular}

Sumber Data : Koesioner diolah Desember 2020

Berdasarkan tabel di atas, maka dari sejumlah 50 responden yang telah diberikan koesioner, terkait pertanyaan tentang fasilitas, ada 35 orang ( $70 \%$ ) menjawab lengkap dan 15 orang $(30 \%)$ menjawab tidak lengkap, hal ini menunjukkan bahwa fasilitas di kapal lengkap.

Tabel 4

Jawaban Informan Tentang Ketersediaan Alat Keselamatan Pelayaran

\begin{tabular}{llcc}
\hline No & Kategori Jawaban & $\begin{array}{c}\text { Frekuensi } \\
\text { (orang) }\end{array}$ & $\begin{array}{c}\text { Presentase } \\
(\%)\end{array}$ \\
\hline 1 & Tersedia & 50 & 100 \\
2 & Tidak tersedia & 0 & 0 \\
\hline & Jumlah & 50 & 100 \\
\hline
\end{tabular}

Sumber Data : Koesioner diolah Desember 2020

Berdasarkan tabel di atas, maka dari sejumlah 50 responden yang telah diberikan koesioner, terkait pertanyaan tentang ketersediaan alat keselamatan selama dalam pelayaran , ada 50 orang ( $100 \%$ ) menjawab tersedia alat keselamatan selama pelayaran, dan 0 orang $(0 \%)$ menjawab tidak tersedia alat keselamatan dalam pelayaran, hal ini menunjukkan bahwa alat keselamatan dalam pelayaran tersedia.

\section{Tabel 5}

Jawaban Informan Tentang Apakah ada Penjelasan tentang Tempat dan Cara Penggunaan Alat Keselamatan Sebelum Pelayaran

\begin{tabular}{clcc} 
No & Kategori Jawaban & $\begin{array}{c}\text { Frekuensi } \\
\text { (orang })\end{array}$ & $\begin{array}{c}\text { Presentase } \\
(\%)\end{array}$ \\
\hline 1 & Ada Penjelasan & 0 & 0 \\
2 & Tidak ada Penjelasan & 50 & 100 \\
\hline & Jumlah & 50 & 100 \\
\hline
\end{tabular}

Sumber Data : Koesioner Diolah Desember 2020

Berdasarkan tabel di atas, maka dari sejumlah 50 responden yang telah diberikan koesioner terkait pertanyaan tentang tempat dan cara penggunaan keselamatan, ada 0 orang ( $0 \%$ ) menjawab ada penjelasan sebelum pelayaran, dan 50 orang $(100 \%)$ menjawab tidak ada penjelasan sebelum pelayaran, hal ini menunjukkan bahwa tidak ada penjelasan dari pihak yang berwenang tentang upaya dalam keselamatan pelayaran.

Sebelum kapal berlayar maka nahkoda memberikan clearing declaration kepada syahbandar, selanjutnya syahbandar harus meneliti apakah dokumen lengkap dan masih berlaku, apakah Nakhoda dan awak kapal lengkap dan memenuhi syarat-syarat ijazah yang ditentukan, apakah awak kapal memiliki buku pelaut dan sertifikat. Dari uraian di atas, dapat dilihat bahwa Syahbandar secara langsung turut berperan dan menunjang kelancaran pelayaran dan angkutan laut melalui pelaksanaan tugas pengawasan terhadap keselamatan kapal dan keselamatan berlayar. Secara teori, Syahbandar memiliki landasan hukum internasional dan nasional untuk melakukan pengawasan dan penegakan hukum 
agar tidak terjadi kecelakaan pelayaran. Dalam pemberian surat persetujuan berlayar ini juga telah melibatkan sejumlah instansi terkait, Syahbandar sebelum memberikan surat ijin berlayar (port clearance) perlu meneliti kelengkapan dokumen kapal dan jika tidak terdapat hal-hal yang bertentangan dengan peraturan, dan bersifat pelanggaran atau adanya kekurangan pada kapal, surat persetujuan.

Syahbandar harus meneliti apakah dokumen lengkap dan masih berlaku, apakah Nakhoda dan awak kapal lengkap dan memenuhi syarat-syarat ijazah yang ditentukan, apakah awak kapal memiliki buku pelaut dan sertifikat. Dari uraian di atas, dapat dilihat bahwa Syahbandar secara langsung turut berperan dan menunjang kelancaran pelayaran dan angkutan laut melalui pelaksanaan tugas pengawasan terhadap keselamatan kapal dan keselamatan berlayar. Secara teori, Syahbandar memiliki landasan hukum internasional dan nasional untuk melakukan pengawasan dan penegakan hukum agar tidak terjadi kecelakaan pelayaran.

Dalam pemberian surat persetujuan berlayar melibatkan sejumlah instansi terkait, Syahbandar sebelum memberikan surat ijin berlayar (port clearance) perlu meneliti kelengkapan dokumen kapal dan jika tidak terdapat hal-hal yang bertentangan dengan peraturan, dan bersifat pelanggaran atau adanya kekurangan pada kapal, surat persetujuan berlayar tidak diberikan, sampai nakhoda atau perusahaan pelayaran melengkapi kekurangan.

\subsection{Faktor Yang Mempengaruhi Tidak Terlaksananya Tanggung Jawab Hukum Nahkoda Kapal.}

Penyebab tidak terlaksananya tanggung jawab hukum nakhoda kapal sangat bervariasi, penyebab ini muncul karena lemahnya pengawasan terhadap standar keselamatan pelayaran, oprasional dari penggunaan kapal masuk dalam faktor internal, artinya bahwa kecelakaan diakibatkan oleh faktor-faktor internal dalam kapal itu sendiri, yang berpengaruh pada keselamatan dan keamanan kapal pada saat berlayar. Dari beberapa kasus kecelakaan kapal di indonesia penyebab terbesar adalah kelebihan beban atau muatan hal ini diakibatkan dari kurangnya pengawasan pihak yang berwenang, selain faktor tersebut banyak juga kecelakaan kapal yang disebabkan oleh kesalahan manusia ( human error ) ataupun disebabkan faktor alam oleh sebab itu diperlukan awak kapal yang propesional dalam menjalankan kapal-kapal di wilayah perairan indonesia.

Beberapa hasil wawancara dari Nakhoda kapal dalam Negeri dan Luar negeri diantaranya :

a. Amin.M.Dewa.,Nakhoda kapal Tanker, mengatakan bahwa salah satu faktor tidak terlaksananya tanggung jawab hukum nakhoda disebabkan kurangnya pengawasan dan pelaksanaan sanksi oleh pihak yang berwenang terhadap pelanggaran yang terjadi dalam pelayaran serta pemantauan dari pihak perusahaan pelayaran yang masih kurang .

b. Gusrah, nakhoda kapal Tanker, mengatakan penyebab tidak terlaksananya tanggung jawab hukum Nakhoda adalah kurang kompetensi dan skill dari Nakhoda itu sendiri serta mental dan disiplin yang kurang dalam menjalankan tugas sebagai Nakhoda.

c. Tasbih Rachman Nakhoda kapal suplay yang beroprasi diluar perairan Indonesia mengatakan salah satu penyebab tidak terlaksananya tanggung jawab hukum nahkoda dalam keselamatan pelayaran adalah disebabkan karna beberapa oknum nahkoda yang tidak menguasai atau tidak memahami aturan-aturan yang berlaku dalam undang-undang pelayaran,faktor lainnya adalah kelalaian dan tidak disiplinnya Nahkoda dalam menjalankan tugas.

d. Alwi Sibali Nakhoda kapal suplay menyampaikan bahwa yang menjadi faktor tidak terlaksananya tanggung jawab hukum nakhoda adalah kurangnya pemahaman terhadap undang-undang pelayaran serta kelalaian dalam pelaksanaan tugas,disamping itu pengawasan pihak yang berwenang yang masih lemah mengenai kompetensi seorang nahkoda.

e. Abdul Rahman, nakhoda kapal pasegger berpendapat faktor tidak terlaksannya tanggung jawab hukum nahkoda karena adanya faktor emergency disebabkan karena faktor eksternal seperti kondisi cuaca yang buruk yang menyebabkan Nakhoda tidak bisa berkonsentrasi dalam pengambilan keputusan ,faktor lainnya karna crew kapal yang tidak solid dan kurangnya skil atau kemampuan dalam melaksanakan tugasnya,terkadang juga disebabkan karna mutasi dari pihak perusahan pelayaran yang mengharuskan Nakhoda berpindah ke kapal jenis dan type yang belum di kuasai oleh Nahkoda tersebut.

f. Rudy nakhoda kapal kontainer, mengatakan faktor yang menyebabkan tidak terlaksananya tanggung jawab hukum nahkoda adalah disebabkan adanya dualisme kepemimpinan di atas kapal dimana pihak pelayaran terkadang lebih mempercayai perwira lain selain nahkoda.

Sebelum kapal berlayar maka nahkoda memberikan clearing declaration kepada syahbandar, selanjutnya syahbandar harus meneliti apakah dokumen lengkap dan masih berlaku, apakah Nakhoda dan awak kapal lengkap dan memenuhi syarat-syarat ijazah yang ditentukan, apakah awak kapal memiliki buku pelaut dan sertifikat. Dari uraian di atas, dapat dilihat bahwa Syahbandar secara langsung turut berperan dan menunjang kelancaran pelayaran dan angkutan laut melalui pelaksanaan tugas pengawasan terhadap keselamatan kapal dan keselamatan berlayar. Secara teori, Syahbandar memiliki landasan hukum internasional dan nasional untuk melakukan pengawasan dan penegakan hukum agar tidak terjadi kecelakaan pelayaran. Dalam pemberian surat persetujuan berlayar ini juga telah melibatkan sejumlah instansi terkait, Syahbandar sebelum memberikan surat ijin berlayar (port clearance) perlu meneliti kelengkapan dokumen kapal dan jika tidak terdapat hal-hal yang bertentangan dengan peraturan, dan bersifat pelanggaran atau adanya kekurangan pada kapal, surat persetujuan berlayar tidak diberikan, sampai nakhoda atau perusahaan pelayaran melengkapi kekurangandi atas maka dari sejumlah 50 responden yang telah diberikan koesioner, terkait pertanyaan tentang tempat dan cara penggunaan alat.

Keselamatan pelayaran tidak terlepas dari peran Syahbandar karena persoalan terbesar terjadinya kecelakaan pelayaran diawali dari diabaikannya prosedur atau dengan kata lain Syahbandar tidak melaksanakan tugas sebagaimana mestinya. Keberadaan Syahbandar merupakan manisfestasi dari bentuk kehadiran Pemerintah dalam lalu lintas laut sehingga selain hubungan hukum privat maka hubungan hukum publik pun nyata ada dalam sistem transportasi laut, sehingga seluruh aktifitas pelayaran diatur oleh pemerintah 
sebagaimana diatur pada undang-undang Nomor 17 Tahun 2008. Dalam Undang tersebut telah diatur secara tegas tugas dan tanggung jawab dari Syahbandar. Syahbandar sebagai pejabat tertinggi dalam kepelabuhan tentunya memiliki kewenangan yang besar yang diberikan oleh aturan hukum Indonesia, oleh Undang-Undang Nomor 17 Tahun 2008 tentang Pelayaran memiliki tugas sebagai berikut :

1) Mengawasi kelaiklautan kapal, keselamatan, keamanan, dan ketertiban dipelabuhan;

2) Mengawasi tertib lalu lintas kapal diperairan pelabuhan dan alur pelayaran.

3) Mengawasi kegiatan alih muat diperairan pelabuhan;

4) Mengawasi pemanduan mengawasi kegiatan penundaan kapal;

5) Mengawasi kegiatan pekerjaan bawah air dan salvage;

6) Mengawasi bongkar muat barang berbahaya;

7) Mengawasi pengisian bahan bakar;

8) Mengawasi pengerukan dan rekalmasi

9) Mengawasi kegiatan pembangunan fasilitas pelabuhan.

Dalam melakukan tugas yang dipercayakan sebagai pemimpin tertinggi di pelabuhan maka Syahbandar memiliki fungsi, yaitu:

1) Melaksanakan fungsi keselamatan dan keamanan dalam pelayaran yang mencakup, pelaksanaan, pengawasan, dan penegakan hukum di bidang angkutan perairan;

2) Syahbandar membantu tugas pencarian dan penyelamatan dipelabuhan sesuai dengan ketentuan perundang-undangan; dan

3) Syahbandar diangkat oleh menteri setelah memenuhi persyaratan kompetensi di-bidang keselamatan dan keamanan serta kesyahbandaran.

Dalam melaksanakan fungsi dan tugas diatas maka Syahbandar memiliki kewenangan sebagai berikut:

1) Mengkoordinasi seluruh kegiatan pemerintahan dipelabuhan

2) Memeriksa dan menyimpan surat,dokumen, dan warta kapal

3) Menerbitkan persetujuan kegiatan kapal dipelabuhan melakukan pemeriksaan kapal

4) Menerbitkan surat persetujuan berlayar

5) Melakukan pemeriksaan kecelakaan kapal; dan

6) Melaksanakan sijil awak kapal.

Peran syahbandar dalam bidang pengawasan adalah sangat penting hal ini dapat dilihat dalam undang-undang pelayaran Indonesia mengenai keselamatan kapal ada beberapa hal yang perlu mendapat perhatian dari syahbandar dalam pengawasannya yaitu:

1) Material kapal

2) Konstruksi kapal

3) Bangunan kapal

4) Permesinan dan perlistrikan kapal

5) Stabilitas kapal

6) Tata susunan serta perlengkapan termasuk perlengkapan alat penolong; dan

7) Radio, alat navigasi dan elektornika kapal.

Sebagai bukti bahwa kapal telah memenuhi semua peraturan yang diharuskan maka kapal tersebut diberikan berbagai sertifikat sesuai dengan kategori kapal diantaranya, sertifikat kesempurnaan, sertifikat garis muat, sertifikat radio kapal dan sertifikat MARPOL. Sebagaimana telah dijelaskan pada bagian sebelumnya ternyata telah terjadi penyimpangan dalam pemberian sertifikat, berlayar adalah kasus lama yang sering terjadi berulang-ulang di Indonesia dan menjadi suatu fenomena yang dianggap biasa.
Salah satu peran penting syahbandar dapat kita lihat dari kewenangannya dalam memeriksa, menyimpan, serta menerbitkan dokumen dokumen yang diperlukan angkutan laut (kapal) agar dapat melakukan pelayaran serta kegiatan bongkar muat barang muatan. Dokumen atau surat-surat yang dimaksud di atas adalah berupa sertifikat kelaiklautan kapal, surat persetujuan berlayar, surat persetujuan berlabuh, surat keterangan barang muatan, sertifikat pendaftaran kapal, sertifikat garis muat internasional, sertifikat perlengkapan keselamatan, sertifikat radio dan telegrap keselamatan, kwitansi penerimaan bea mercusuar Indonesia pada pelayaran yang terakhir, dan izin masuk-keluar dari pelabuhan yang terakhir disinggahi.

Salah satu dokumen penting yang juga merupakan dokumen penentu agar sebuah kapal (angkutan laut) dapat melakukan pelayaran adalah Surat Persetujuan Berlayar, sebagaimana tercantum dalam Pasal 219 Undang- Undang Nomor 17 tahun 2008 tentang pelayaran, yang berbunyi " Setiap kapal yang berlayar wajib memiliki Surat Persetujuan Berlayar yang dikeluarkan oleh syahbandar "dan surat persetujuan berlayar tidak berlaku apabila kapal dalam waktu 24 (dua puluh empat) jam setelah persetujuan berlayar diberikan, sebagaimana yang telah penulis sampaikan diatas, dengan sudah tidak berlakunya surat persetujuan berlayar maka seharusnya kapal tidak bertolak dari pelabuhan. Penerbitan surat persetujuan berlayar diberikan kepada kapal setelah perusahaan pelayaran melakukan serangkaian mekanisme pengurusan yang meliputi pengajuan permohonan penerbitan surat persetujuan berlayar secara tertulis kepada syahbandar dengan melampirkan:

1) Surat pernyataan kesiapan kapal (Master Sailing Declaration);

2) Dokumen muatan serta bukti-bukti pemenuhan kewajiban kapal lainnya.

Pemenuhan kewajiban kapal yang dimaksud diatas berupa, bukti pembayaran jasa kepelabuhanan, bukti pembayaran jasa kenavigasian, bukti pembayaran penerimaan uang perkapalan, persetujuan bea dan cukai, persetujuan imigrasi, persetujuan karantina kesehatan, dan persetujuan karantina hewan dan tumbuhan. Pejabat kesyahbandaran setelah menerima permohonan dari perusahaan pelayaran atau agen yang mewakili melakukan verifikasi/pemeriksaan sertifikat dan dokumen kapal dan melakukan verifikasi/pemeriksaan fisik kapal yang dinyatakan dengan layak untuk berlayar. Sebelum pemberian surat persetujuan berlayar seorang syahbandar harus memastikan bahwa kapal yang akan melakukan pelayaran harus memenuhi beberapa unsur penting demi terlaksananya fungsi keselamatan dan keamanan pelayaran. Setelah itu, barulah surat persetujuan berlayar diberikan terhadap kapal.

Setiap kapal yang berlayar selalu diawaki oleh Tim yang terdiri dari beberapa orang (tergantung dari besar kecilnya kapal), yang didalam undang-undang pelayaran tim tersebut dinamakan awak kapal. Awak kapal adalah orang yang bekerja atau dipekerjakan di atas kapal oleh pemilik atau operator kapal untuk melakukan tugas di atas kapal sesuai dengan jabatannya yang tercantum dalam buku sijil, yang termasuk awak kapal yaitu nakhoda kapal, anak buah kapal (ABK), perwira dan kelasi. nakhoda kapal adalah salah seorang dari awak kapal yang menjadi pemimpin tertinggi di kapal dan mempunyai wewenang dan tanggung jawab tertentu sesuai dengan ketentuan peraturan perundang-undangan. Nakhoda wajib bertindak dengan kepandaian, ketelitian dan dengan kebijaksanaan yang cukup untuk melaksanakan 
tugasnya dengan baik. Nakhoda pada dasarnya merupakan orang yang paling bertanggung jawab terhadap semua hal yang terjadi di kapal. Dia dituntut untuk mengetahui dan memahami semua karakteristik tiap-tiap unit di kapal yang bersangkutan, baik yang secara langsung berkaitan dengan pengoperasian kapal maupun yang hanya bersifat membantu pelayaran. Disamping itu Nakhoda harus paham benar mengenai jumlah penumpang maupun muatan kapal serta barang-barang lain sebagai kelengkapan kapal.

Nakhoda wajib mentaati dengan seksama peraturan yang lazim dan ketentuan yang ada untuk menjamin kesanggupan berlayar dan keamanan kapal, keamanan para penumpang dan pengangkutan muatannya. Ia tidak akan melakukan perjalanannya, kecuali bila kapalnya untuk melaksanakan itu memenuhi syarat, dilengkapi sepantasnya dan diberi anak buah kapal secukupnya. Nakhoda wajib memberi pertolongan kepada orang-orang yang ada dalam bahaya yang berada dalam kapal. Nakhoda tidak boleh meninggalkan kapalnya selama pelayaran atau bila ada bahaya mengancam. tugas dan tanggung jawab nakhoda kapal sangat banyak dan berat baik sebelum maupun selama pelayaran. Bahkan menurut hukum Internasional, nakhoda dapat bertindak untuk dan atas nama negara bendera kapal yang berwenang untuk memutuskan segala sesuatu yang berkaitan dengan keselamatan navigasi maupun keamanan pelayaran antara lain meminta izin kepada negara pantai dalam kaitannya menggunakan hak lintas damai, memasuki selat-selat sempit yang sesuai dengan karakteristik kapalnya.

Nakhoda kapal mempunyai peranan penting dalam kapal, karena yang mengemudikan kapal tersebut selamat sampai tempat tujuan. Nakhoda kapal memikul tanggung jawab penting dalam sebuah kapal. Tugas seorang Nakhoda kapal adalah bertanggung jawab ketika membawa sebuah kapal dalam pelayaran, baik itu dari pelabuhan satu menuju ke pelabuhan lainnya dengan selamat.

Adapun tugas dari seorang nakhoda antara lain sebagai pemegang Kewibawaan Umum, artinya semua orang yang berada di atas kapal, siapapun dia tanpa kecuali wajib patuh kepada perintah-perintah yang di berikan oleh seorang Nakhoda, hal ini demi terciptanya keamanan serta ketertiban di atas kapal. Sehingga tidak ada satu alasan apapun yang dibuat oleh orang-orang yang ada di atas kapal untuk menentang dari perintah yang diberikan oleh seorang Nakhoda kapal selama perintah itu masih sesuai dengan aturan serta tidak menyimpang dari peraturan perundang-undangan. Jika terdapat penentangan terhadap perintah dari Nakhoda, hal ini merupakan pelanggaran hukum, dan ini sesuai dengan pasal 459 dan 460 KUH. Pidana.

Tugas lain seorang nakhoda dapat pula menjadi penegak hukum di atas kapal dan hal-hal lain yang berkaitan dengan kepentingan para penumpang kapal selaku warga negara (sesuai bendera kapal). Sebagai contoh apabila dalam sebuah kapal terjadi peristiwa kelahiran atau kematian maka seorang nakhoda kapal berwenang untuk bertindak selaku Pegawai Catatan Sipil. Oleh karenanya nakhoda berwenang untuk membuat berita acara kelahiran maupun kematian dan mancatatnya dalam buku harian kapal untuk selanjutnya menyerahkan Berita Acara tersebut kepada kantor Catatan Sipil di pelabuhan pertama yang disinggahi. apabila hal tersebut terjadi di luar perairan negara bendera kapal, maka berita acara kelahiran maupun kematian tersebut diserahkan kepada kantor kedutaan besar negara bendera yang berada di negara yang disinggahi. Hal tersebut menunjukkan betapa banyak dan berat tugas seorang nakhoda di atas kapal.

Dipidananya seseorang tidaklah cukup orang itu telah melakukan perbuatan yang bertentangan dengan hukum. Untuk itu pemidanaan masih perlu adanya syarat, yaitu bahwa orang yang melakukan perbuatan itu mempunyai kesalahan atau bersalah (subjective guilt). hal ini tergantung pada "apakah dalam melakukan perbuatan ini orang tersebut mempunyai kesalahan. Nakhoda yang dipidana jika tidak ada kesalahan (geen straf zonder schuld:actus non facit reum nisi mens sir rea)", apakah perbuatan tersebut dilakukan secara sengaja atau kelalaian. Tentunya kalau ditinjau dari UndangUndang Nomor 17 Tahun 2008 tentang Pelayaran, bahwa perbuatan pidana yang mungkin dapat dilakukan oleh nakhoda kapal diantaranya adalah :

1) mengemudikan kapal dan menyebabkan tubrukan dengan kapal laut lainnya

2) memberikan perintah kepada awak kapal untuk melakukan kejahatan

3) mengambil keputusan dalam kapal dengan putus asa sehingga kapal laut diabaikan

4) mengemudikan kapal laut, sedangkan sertifikat khusus untuk mengemudikan kapal tidak punya

5) mengabaikan aturan sarana bantu navigasi

6) memaksakan kapal dijalankan ketika berlabuh tanpa persetujuan Syahbandar; dan

7) Nakhoda mengabaikan dan meninggalkan kapal laut tanpa seijin pemilik kapal laut.

Tanggung jawab perusahaan pelayaran dalam hubungan kerja di bidang transportasi laut, kita mengenal adanya 3 kelompok orang, yaitu pengusaha kapal atau perusahaan pelayaran, nakhoda dan anak buah kapal, baik sebagai perwira kapal ataupun klasi. Tiap-tiap orang yang terlibat bekerja dalam kapal harus bekerja sama dengan baik agar tujuan dari pelayaran itu terpenuhi. Ketiga pihak yang terlibat tersebut, umumnya terikat oleh suatu perjanjian tertentu, dan harus memiliki izin tertentu untuk dapat bekerja sama dalam sebuah usaha pelayaran. Ini tentu saja dimaksudkan agar tiap-tiap pihak dapat bekerja dengan penuh tanggung jawab, sesuai dengan apa yang telah tertuang dalam surat izin ataupun perjanjian tersebut. Sehingga apabila terjadi suatu masalah dalam pelayaran yang disebabkan oleh human error, maka akan dengan langsung dapat diketahui dan diantisipasi, sehingga tidak menyebabkan terjadinya masalah yang lebih besar.

Bagaimanapun kecakapan seluruh awak kapal dalam menempuh suatu pelayaran, resiko akan terjadinya kecelakaan kapal ditengah laut tetap ada. Sehingga dibutuhkan pengawasan yang baik dan ketat atas sebuah kapal dalam pelayaran. Pengawasan terhadap keselamatan (safety) dari Perusahaan Pelayaran terhadap kapal yang berlayar telah diatur dalam International Safety Management Code (ISM Code) yaitu merupakan aturan standar internasional tentang manajemen keselamatan dalam pengoperasian kapal serta upaya pencegahan/ pengendalian pencemaran lingkungan. Sesuai dengan kesadaran terhadap pentingnya faktor manusia dan perlunya peningkatan manajemen operasional kapal dalam mencegah terjadinya kecelakaan kapal, manusia, muatan barang / cargo dan harta benda serta mencegah terjadinya pencemaran lingkungan laut, maka IMO mengeluarkan peraturan tentang manajemen keselamatan 
kapal \& perlindungan lingkungan laut yang dikenal dengan ISM Code yang juga dikonsolidasikan dalam SOLAS Convention.

Pada dasarnya ISM Code mengatur adanya manajemen terhadap keselamatan (safety) baik Perusahaan Pelayaran maupun kapal termasuk SDM yang menanganinya. Untuk Perusahaan Pelayaran, harus ditunjuk seorang setingkat Manajer yang disebut DPA (Designated Person Ashore/Orang yang ditunjuk di darat). Ia bertanggung jawab dan melakukan pengawasan terhadap keselamatan (safety) dari Perusahaan Pelayaran tersebut. Manajer penanggung jawab ini harus bertanggung jawab dan mempunyai akses langsung kepada Pimpinan tertinggi (Direktur Utama/Pemilik Kapal) dari Perusahaan Pelayaran tersebut.

Peran Komite Nasional Keselamatan Transportasi (KNKT) dalam penanggulangan keselamatan pelayaran. Berdasarkan visi komite nasional keselamatan transportasi adalah meningkatnya keselamatan transportasi dengan berkurangnya kecelakaan oleh penyebab serupa, sedangkan misi yang diemban adalah:

1) Melaksanakan kegiatan investigasi dan penelitian yang meliputi analisis dan evaluasi sebab-sebab terjadinya kecelakaan transportasi

2) Melaksanakan penyusunan rekomendasi sebagai bahan masukan bagi perumusan kebijakan keselamatan transportasi dan upaya pencegahan kecelakaan transportasi; dan

3) Melaksanakan penelitian penyebab kecelakaan transportasi dengan bekerja sama dengan organisasi profesi yang berkaitan dengan penelitian penyebab kecelakaan transportasi dalam rangka mewujudkan visi KNKT.

Dalam ketentuan Pasal 256 tentang Investigasi Kecelakaan, Undang-Undang Nomor 17 Tahun 2008 tentang Pelayaran kapal dinyatakan bahwa:

1) Investigasi kecelakaan kapal dilakukan oleh komite nasional keselamatan transportasi untuk mencari fakta guna mencegah terjadinya kecelakaan kapal dengan penyebab yang sama;

2) Investigasi sebagaimana dimaksud pada ayat (1) dilakukan terhadap setiap kecelakaan kapal; dan

3) Investigasi yang dilakukan oleh komite nasional keselamatan transportasi sebagaimana dimaksud pada ayat (1) tidak untuk menentukan kesalahan atau kelalaian atas terjadinya kecelakaan kapal.

Komite nasional keselamatan transportasi, bertanggung jawab untuk melakukan investigasi atas kecelakaan transportasi baik darat, laut maupun udara kemudian memberikan usulan-usulan perbaikan agar kecelakaan yang sama tidak lagi terjadi pada masa depan. KNKT melakukan investigasi kecelakaan didasarkan pada aspek legalitas berupa Undang-Undang Nomor 17 tahun 2008 tentang Pelayaran dan Keputusan Presiden Nomor 105 Tahun 1999, yang didalamnya mengatur tugas pokok dan fungsinya:

1) Melakukan investigasi dan penelitian yang meliputi analisis dan evaluasi sebab-sebab terjadinya kecelakaan transportasi;

2) Memberikan rekomendasi bagi penyusunan perumusan kebijaksanaan keselamatan transportasi dan upaya pencegahan kecelakaan transportasi;

3) Melakukan penelitian penyebab kecelakaan transportasi dengan bekerja sama dengan organisasi profesi yang berkaitan dengan penelitian penyebab kecelakaan transportasi.

Untuk melaksanakan tugas tersebut, KNKT mempunyai wewenang antara lain: memasuki tempat kejadian kecelakaan, mengumpulkan barang bukti, mengamankan on board recording $(O B R)$, memanggil dan meminta keterangan saksi, menentukan penyebab kecelakaan transportasi dan membuat rekomendasi keselamatan transportasi agar kecelakaan dengan penyebab yang sama tidak terjadi lagi. Wewenang dalam melakukan investigasi oleh KNKT kecelakaan transportasi secara eksplisit sebagaimana diatur dalam Undang-Undang Nomor 17 tahun 2008 tentang Pelayaran.

Sebelum adanya Undang-undang Pelayaran Nomor 21 tahun 1992 yang sekarang telah diganti dengan Undangundang Nomor 17 Tahun 2008 Tentang Pelayaran, Secara yuridis perbuatan-perbuatan yang termasuk kedalam tindak pidana dibidang pelayaran diatur secara eksklusif didalam Kitab Undang-undang Hukum Pidana (KUHP), yakni dalam buku kedua, Bab XXIX tentang kejahatan pelayaran, Pasal 438 sampai dengan Pasal 479, meliputi pembajakan, keterangan palsu isi surat ijin berlayar, pelanggaran perjanjian, dan penyerangan nakhoda. Namun sejak berlakunya Undang-Undang Nomor 17 Tahun 2008 tentang pelayaran pengaturan mengenai tindak pidana di bidang Pelayaran delik pidana bertambah dan pelakunya bukan hanya manusia tetapi juga dapat dilakukan oleh korporasi. Hal ini Sebagaimana dinyatakan dalam Pasal 333 undang-undang pelayaran, bahwa "Tindak pidana di bidang pelayaran dianggap dilakukan oleh korporasi apabila tindak pidana tersebut dilakukan oleh orang-orang yang bertindak untuk dan/atau atas nama korporasi atau untuk kepentingan korporasi, baik berdasarkan hubungan kerja maupun hubungan lain, bertindak dalam lingkungan korporasi tersebut baik sendiri maupun bersama-sama". Dimana penyidikan, penuntutan, pemidanaan terhadap tindak pidana di bidang pelayaran yang dilakukan oleh korporasi dapat dilakukan terhadap korporasi maupun pengurusnya. Selain itu penjatuhan pidana denda juga dapat diperberat sampai 3 kali penjatuhan denda yang diatur dalam undang-undang pelayaran. Meskipun terdapat perluasan subjek dalam undangundang pelayaran, akan tetapi undang-undang pelayaran tidak mengatur mengenai tindak pidana pembajakan sebagaimana yang diatur didalam KUHP.

\section{KESIMPULAN DAN SARAN}

Hasil penelitian dan pembahasan dapat disimpulkan bahwa secara hukum, tanggung jawab hukum di atas kapal dipegang oleh nahkoda kapal atas keselamatan dalam pelayaran. Dalam pelaksanaan tanggung jawab belum sepenuhnya dilaksanakan dengan memadai. Faktor yang menyebabkan tidak terlaksananya tanggung jawab Hukum Nahkoda Kapal berupa kurangnya skill dari nakhoda itu sendiri,serta mental dan disiplin yang kurang dalam menjalankan tugas selama pelayaran serta kurangnya pemahaman terhadap undang-undang pelayaran dan pengawasan dari pihak yang berwenang masih kurang terlaksana dengan baik dan kondisi alam seperti cuaca yang buruk yang menyebabkan nakhoda tidak bisa berkonsentrasi dalam pengambilan keputusan. 


\section{DAFTAR PUSTAKA}

Abdullah M K , 2012. Terbaru Kamus Besar Bahasa Indonesia Sandro Jaya. Jakarta

Hamzah, Andi 1986. Kamus Hukum Ghalia Indonesia Jakarta. Cetakan- 1

Kartini, 2013. Hukum Maritim. Deepublish Publisher Yogyakarta. Edisi pertama Cetakan - 2

Munir Fuady, 2010 perbuatan melawan hukum pendekatan kontemporer,Citra Aditya Bakti ,Bandung

Widjaja Gunawan Dan Yani Ahmad 2001,Hukum Tentang Perlindungan Konsumen.Jakarta PT SUN Cetakan ke-2

Sumber Direktorat ,Lalu Lintas Laut, Direktorat Jenderal Perhubungan Laut

Standar Of Training Cerfititation And Watc Keeping

Sukarmi. 2005, Tanggung jawab pelaku usaha atas kerugian konsumen yang disebabkan oleh perjanjian baku. Disertasi Doktor Unpad Bandung

Titik Triwulan dan Shinta Febrian.2010 Perlindungan Hukum bagi pasien Prestasi Pustaka Jakarta

Tjakranegara Soegijatna, 2018. Hukum Pengangkutan Barang Dan Penumpang Rineka cipta. Jakarta

Peraturan Pemerintah Republik Indonesia 51/Tahun 2002 Tentang Perkapalan

Moeljatno, 2001. Kitab Undang- Nova Noval Dwinuari Antony 2018 .Detik News kecelakaan pelayaran terjadi dalam waktu dekat apa yang salah.

Dwinuari Antony 2018 .Detik News kecelakaan pelayaran terjadi dalam waktu dekat apa yang salah.

Undang Hukum Pidana Bumi Aksara Jakarta.Cetakan - 21

Https://id.wikipedia.org/wiki/daftar-kecelakaan diakses pada tanggal 5 Desember 2020

http://id.wikipedia.org/wiki/Daftar kecelakaan dan insiden kapal di Indonesia ,diakses tanggal 5 Desember 2020

Harnoli Rahman,et.al 2017. Penentuan faktor dominan penyebab kecelakaan kapal di Kesyahbandaran utama Tanjung priok-Albacore volume 1 No 3 277-284

Noval Dwinuari Antony 2018 .Detik News kecelakaan pelayaran terjadi dalam waktu dekat apa yang salah. 